\title{
High levels of filamentous actin and apoptosis correlate with mast cell refractoriness under alloxan-evoked diabetes
}

\author{
Emiliano O. Barreto ${ }^{a}$, Vinícius F. Carvalho ${ }^{a}$, Michelle S. Oliveira ${ }^{a}$, Álvaro L. Bertho ${ }^{\text {b }}$, \\ Thereza C. Barja-Fidalgo ${ }^{c}$, Renato S.B. Cordeiro ${ }^{a}$, Marco A. Martins ${ }^{a}$, Patrícia M.R. e Silva ${ }^{a}, *$ \\ ${ }^{a}$ Laboratory of Inflammation, Department of Physiology and Pharmacodynamics, Brazil \\ ${ }^{\mathrm{b}}$ Laboratory of Immunoparasitology, Department of Immunology, Oswaldo Cruz Institute/FIOCRUZ, Av. Brazil, no 4365, Manguinhos, CEP 21045-900, Brazil \\ ${ }^{\mathrm{c}}$ Department of Pharmacology, State University of Rio de Janeiro, Rio de Janeiro, Brazil
}

Received 27 October 2005; accepted 17 March 2006

\begin{abstract}
Mast cell number and reactivity were shown to be down-regulated under diabetic conditions. Since the balance between globular and filamentous actin plays a pivotal role in the activity of secretory cells, we investigated whether an imbalance in that system could underlie the hyporesponsiveness of mast cells in diabetes. The apoptotic state was also evaluated. By means of rhodamine/phalloidine staining of F-actin, we noted that diabetic mast cells exhibited an increase in fluorescence intensity and reduction in cellular size, when compared with cells from normal animals, in parallel with elevation in the percentage of cells developing apoptosis. The levels of Bax, a pro-apoptotic member of Bcl-2 family, appeared increased at baseline in mast cells from diabetic rats compared with normal cells. These phenomena correlated with reduction in histamine and $\mathrm{PGD}_{2}$ release following antigen challenge in vitro. The steroid antagonist RU 486 abolished the reduction of histamine secretion from diabetic mast cells. We conclude that hyporesponsiveness of mast cells noted in diabetes may be accounted for by reduction in actin filament plasticity, in clear association with the rise in the percentage of cells undergoing apoptosis. In addition, the refractoriness of diabetic mast cells to antigen in vitro seems to be dependent on glucocorticoids.
\end{abstract}

(C) 2006 Elsevier Inc. All rights reserved.

Keywords: Diabetes; Mast cells; Apoptosis; Actin microfilament; Glucocorticoids

\section{Introduction}

Diabetes mellitus represents a heterogeneous group of disorders which are caused by defects in insulin secretion, insulin action or both, translated into abnormalities of carbohydrate, fat and protein metabolism, resulting in hyperglycemia (Klip et al., 1992; Taskinen et al., 1996). It is noteworthy that allergic disorders, including asthma, atopic dermatitis and eczema have an unusual occurrence in diabetic patients (Tinkelman and King, 1979; Bottini and Fontana, 1999; Cardwell et al., 2003; Olesen et al., 2001), though the reason for this mutual exclusion is still debatable.

\footnotetext{
* Corresponding author. Laboratory of Inflammation, Department of Physiology and Pharmacodynamics, Av. Brazil, no 4365, Manguinhos, CEP 21045900, Rio de Janeiro, Brazil. Tel.: +55 212573 0844; fax: +55 2125909490.

E-mail address: patmar@ioc.fiocruz.br (P.M.R. e Silva).
}

In more recent studies we reported that sensitised rats turned diabetic after alloxan treatment exhibited a reduced antigen-induced protein extravasation and leukocyte infiltration in the pleural space (Diaz et al., 1996). Suppression of allergen-evoked pleurisy appeared to be correlated with a decrease in the local mast cell population and an increase in serum corticosterone levels (Diaz et al., 1997, 2001). It is noteworthy that elevation in serum glucocorticoid concentration has already been detected in diabetic patients (Cameron et al., 1984; Roy et al., 1990, 1998). Glucocorticoids act by transcriptionally activating certain sets of genes in susceptible cells, subsequently altering gene expression at various cellular levels (Schoneveld et al., 2004). They have been shown to inhibit exocytosis from several cell types, including pituitary luteotrophs, neutrophils and mast cells (Barnes, 1997), by a mechanism possibly linked to the stabilization of actin cytoskeleton (Castellino et al., 1992). Previous studies 
reported that a network of filamentous actin underlying the plasma membrane can regulate exocytosis by acting as a barrier which hinders the apposition of secretory granule membrane fusion sites (Miyake et al., 2001; Burgess and Kelly, 1987). Glucocorticoids are shown to induce the reorganization and stabilization of the actin cytoskeleton in the pituitary cell as well as in other cell types (Castellino et al., 1992), and this effect contributes to glucocorticoid suppression of ACTH release (Castellino et al., 1995). Interestingly, it has been shown that modification of the actin cytoskeleton impacts upon signal transduction leading to programmed cell death or apoptosis (Pendleton et al., 2003). Apoptosis plays an important role in a wide variety of physiologic and pathologic conditions. The mechanism of this process is highly conserved throughout all eukaryotic cells and involves the Bcl-2 family, which consists of both anti-apoptotic $\left(\mathrm{Bcl}-2, \mathrm{BclX}_{\mathrm{L}}\right)$ and proapoptotic $\left(\mathrm{BclX}_{\mathrm{S}}, \mathrm{Bax}, \mathrm{Bak}\right)$ factors (Cohen-Saidon et al., 2003). Considering the observations above, this study was undertaken to investigate whether an imbalance between globular and filamentous actin and/or enhanced apoptosis could contribute to the refractoriness of mast cells under the condition of experimental diabetes by alloxan in rats. The involvement of glucocorticoids in this phenomenon was also assessed.

\section{Materials and methods}

\section{Animals and diabetes induction}

Male Wistar rats (180-200 g) were obtained from the Oswaldo Cruz Foundation breeding. All the procedures involving care and use of laboratory animals in this study were examined and approved by the Animal Ethics Committee of the Oswaldo Cruz Foundation (licence 0085-02). Diabetes was induced by a single injection of alloxan ( $40 \mathrm{mg} / \mathrm{kg}$, i.v.), diluted with sterile saline into $12 \mathrm{~h}$-fasted anaesthetized rats. Blood glycemia was determined by means of a glucose monitor in samples obtained from the tail vein. Only rats with glucose levels $>10 \mathrm{mM}$ were considered in further experiments.

\section{Surgical bilateral adrenalectomy}

Seven days before diabetes induction, anaesthetized rats were submitted to bilateral adrenalectomy through a dorsal incision. Sham-operated animals were submitted to the same surgical manipulation, but adrenal glands were left intact. Both groups were maintained on a normal diet and allowed free access $0.9 \%$ saline until the analyses.

\section{Mast cell purification and stimulation}

After 21 days of alloxan injection, the animals were sacrificed in $\mathrm{CO}_{2}$ chamber and mast cells isolated by continuous Percoll gradient (de Oliveira Barreto et al., 2003). Peritoneal mast cells were recovered from rats after wash with heparinized $(10 \mathrm{UI} / \mathrm{ml})$ HBSS calcium and magnesium free medium ( $\mathrm{HBSS}^{-}$). Cells were centrifuged at

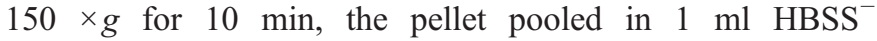
containing $0.1 \%$ bovine serum albumin (BSA) and mixed with $4 \mathrm{ml}$ of $72 \%$ isotonic Percoll overlaid with $1 \mathrm{ml}$ of $\mathrm{HBSS}^{-}$. The gradient was centrifuged at $150 \times g$ for $25 \mathrm{~min}$. Pelleted mast cells were washed twice with $\mathrm{HBSS}^{-}$and purity was more than $99 \%$ as attested by toluidine blue staining. Viability tested by means of trypan blue exclusion was higher than $95 \%$. In the case of antigen stimulation, isolated mast cells $\left(1 \times 10^{5}\right.$ cells $\left./ \mathrm{ml}\right)$ were cultured in 24 -well plates with IgE antiDNP antibody $(0.5 \mu \mathrm{g} / \mathrm{ml})$ at $37{ }^{\circ} \mathrm{C}$ for $12 \mathrm{~h}$. Following sensitization, the cells were incubated with antigen (DNPBSA, $0.05 \mu \mathrm{g} / \mathrm{ml}$ ) for $1 \mathrm{~h}$ at $37{ }^{\circ} \mathrm{C}$ in $5 \% \mathrm{CO}_{2}$ in air. After centrifugation at $150 \times g$, the supernatant was collected and stored at $-20{ }^{\circ} \mathrm{C}$. Mast cells were also stimulated with bradykinin $(50 \mu \mathrm{g} / \mathrm{ml})$. To evaluate the interference of actin cytoskeleton with the secretory function of mast cells, the actin polymerizating agent jasplakinolide (Miyake et al., 2001) $(1 \mu \mathrm{M})$ was added to mast cells, $12 \mathrm{~h}$ before stimulation. In another set of experiments, isolated mast cells were treated with alloxan in vitro $(0.5 \mathrm{mg} / \mathrm{ml}), 1 \mathrm{~h}$ before antigen provocation.

\section{Histamine and $\mathrm{PGD}_{2}$ quantification}

Samples were collected and added to $0.8 \mathrm{~N}$ perchloric acid (1:2 dilution). After centrifugation at $170 \times g$ for $10 \mathrm{~min}$, the supernatant was collected and stored at $-20{ }^{\circ} \mathrm{C}$ for histamine quantification according to Shore et al. (1959). Briefly, this method consists of sample dilution in $0.1 \mathrm{~N} \mathrm{HCl}$ followed by $0.8 \mathrm{~N}$ of $\mathrm{NaOH}$, and further addition of substrate $o$ phtaldialdehyde (OPT). After 4 min incubation, the reaction was stopped with $3 \mathrm{~N} \mathrm{HCl}$ and the fluorescence measured in a Shimadzu RF1501 spectrofluorophotometer (Japan) (excitation at $360 \mathrm{~nm}$; emission at $450 \mathrm{~nm})$. Prostaglandin $\mathrm{D}_{2}\left(\mathrm{PGD}_{2}\right)$ was evaluated by means of an enzyme immunoassay (EIA), following manufacturer's guidelines (Cayman Chemical Co., USA).

\section{Fluorescence microscopy}

Mast cells were fixed on glass cover slips with paraformaldehyde (3\%) for $20 \mathrm{~min}$ at room temperature and then exposed to Triton X-100 (0.1\%) in PBS for 5 min. Cells were stained with rhodamine-labeled phalloidine for $1 \mathrm{~h}$ at room temperature. Cover slips were mounted on clean slides using a solution of $\mathrm{N}$ propylgalected $(20 \mathrm{nM})$ plus glycerol $(20 \%)$ in PBS, and analyzed under a fluorescence microscope (Olympus BX-50), which was coupled to a video-camera (Optronics Engineering, DEI-750). Quantitative analysis of fluorescent images was performed by Image-Pro Plus 4 software (Media Cybernetics) measuring cell surface area (in pixels) reported as arbitrary units (a.u.).

\section{Detection of apoptosis by flow cytometry}

In order to access the DNA cleavage, hypotonic propidium iodide (PI) method was used as described (Nicoletti et al., 
1991). Briefly, $1 \times 10^{6}$ of mast cells were washed twice with PBS and suspended in $1 \mathrm{ml}$ hypotonic PI solution (PI, $50 \mu \mathrm{g} /$ $\mathrm{ml}$, in $0.1 \%$ sodium citrate containing $0.1 \%$ Triton $\mathrm{X}-100$ in PBS). PI-stained nuclei with less than normal fluorescence intensity (hypodiploid) were shown to have DNA which was fragmented and lower than normal in quantity (Afanasyev et al., 1993). The PI fluorescence of individual nuclei was measured by an EPICS ALTRA flow cytometer (Beckman Coulter, Hialeah, FL) equipped with an Enterprise II dual argon/UV laser. A $610 \mathrm{~nm}$ band pass filter was used for collecting the red fluorescence due to PI staining of DNA and the data were registered on a logarithmic scale. All the data were recorded by Expo32 software (Beckman Coulter). Cell debris was excluded from analysis by appropriately raising the forward scatter threshold. As there was no overlap between apoptosis nuclei and debris, the small percentage of residual low-fluorescent detritus was eliminated by gating (Apo) at channel 10 on the red PI fluorescence scale. The flow rate was set at about 200 nuclei $\mathrm{s}^{-1}$ and at least $1.5 \times 10^{4}$ cells of each sample were acquired.

\section{Western blot for Bax and Bcl-2}

Mast cell $\left(2 \times 10^{6}\right.$ cells $)$ lysate was prepared in $10 \%$ SDS, $40 \mathrm{mM}$ Tris- $\mathrm{HCl}, 10 \mathrm{mM}$ EDTA, $60 \mathrm{nM}$ sodium pirofosfate and $10 \% \beta$-mercaptoethanol. Ten micrograms of lysate were resolved on a $10 \%$ SDS-PAGE acrylamide gel and transferred to nitrocellulose by means of an electroblotting apparatus. The blot was blocked overnight in TTBS (25 mM Tris, $\mathrm{pH} 7.8,0.20 \%$ Tween-20 and $125 \mathrm{mM} \mathrm{NaCl}$ ) containing $5 \%$ nonfat milk on orbital shaker. The membrane was incubated with rabbit antibody anti-Bax and goat antiBcl-2 antibody (1:250 dilution; Santa Cruz), or with goat anti- $\beta$ actin (1:200 dilution, Santa Cruz) overnight at $4{ }^{\circ} \mathrm{C}$. The blot was washed in TTBS. The membrane was incubated with horseradish peroxide (HRP)-conjugated anti- rabbit or goat $\operatorname{IgG}$ diluted 1:3000 with PBS-BSA for $45 \mathrm{~min}$ at room temperature and washed five times for $5 \mathrm{~min}$ in TTBS. The membrane was then incubated with Amersham ECL reagent for $30 \mathrm{~min}$ and exposed to X-ray film for $1 \mathrm{~min}$ in a dark room. Protein expression was quantified by densitometric analysis with Image Software (Image ProPlus for Windows).

\section{Treatments}

Diabetic rats were pretreated with steroid receptor antagonist RU 486, which was dissolved in $0.5 \%$ methylcellulose (v/v in water), and orally administered at $20 \mathrm{mg} / \mathrm{kg}$ from day 2 up to day 21 . In another set of experiments, animals were treated s.c. with either corticosterone $(0.5 \mathrm{mg} / \mathrm{kg})$ or dexamethasone $(0.1 \mathrm{mg} / \mathrm{kg})$ for 5 days.

\section{Drugs}

Dinitrophenylated bovine serum albumin (DNP-BSA) from Calbiochem (San Diego, USA), sodium heparin from Roche (São Paulo, Brazil). The murine anti-DNP IgE mAb was from Calbiochem (San Diego, USA) and alloxan, RU 486, bradykinin, bovine serum albumin, o-phtaldialdehyde (OPT), HBSS, dexamethasone, corticosterone, propidium iodide, jasplakinolide and Percoll were obtained from Sigma Chemical Co (St. Louis, MO). Rhodamine/phalloidine was from R\&D System (USA). All solutions were freshly prepared immediately before use.

\section{Statistical analysis}

The results were expressed as mean \pm standard error of the mean (SEM) and statistically analyzed by means of ANOVA, followed by the Newman-Keuls-Student's $t$ test. Probability values $(p)$ of 0.05 or less were considered significant.
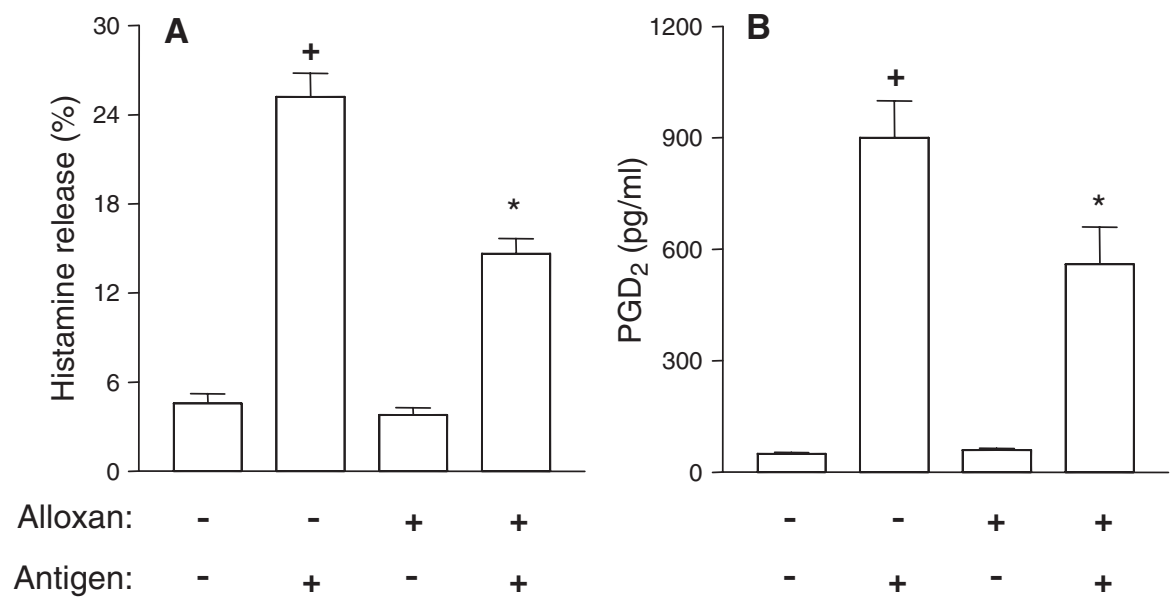

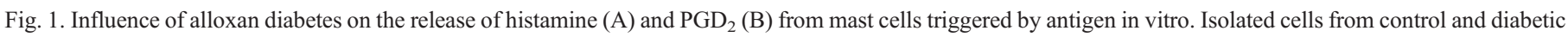

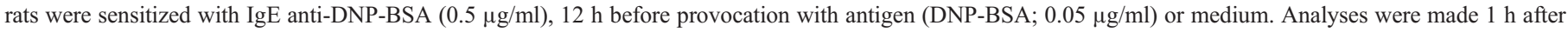

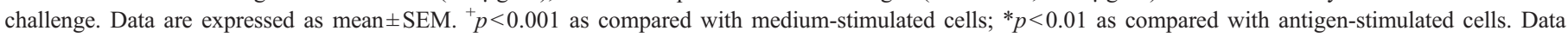
represent at least four independent experiments. 


\section{Results}

\section{Influence of diabetic state on mast cell reactivity in vitro}

Purified peritoneal mast cells, passively sensitized with IgE anti-DNP/BSA and then activated with antigen (DNPBSA, $0.05 \mu \mathrm{g} / \mathrm{ml}$ ), exhibited a marked increase in the levels of histamine and of $\mathrm{PGD}_{2}$ release (Fig. $1 \mathrm{~A}$ and $\mathrm{B}$, respectively), a phenomenon clearly suppressed in mast cells recovered from alloxinated rats (Fig. 1). It is noteworthy that incubation of isolated mast cells with alloxan in vitro did not affect their response to antigen stimulation. Values of histamine release were $21.5 \pm 0.5 \%$ and $21.9 \pm 0.8 \%$ (mean \pm SEM) in control and alloxan-treated mast cells, respectively.

\section{Effect of alloxan diabetes on mast cell actin cytoskeleton}

Stabilization of filamentous actin has been reported to inhibit secretion of various cell types (Burgess and Kelly, 1987; Castellino et al., 1995; Pendleton et al., 2003). To examine whether a link might exist between cytoskeletal reorganization and down-regulation of mast cell secretory function, under diabetic conditions, isolated mast cells were perfused with rhodamine-phalloidine, a fluorescent dye capable of staining filamentous actin selectively (White et al., 2001). We noted that mast cells from 21-day diabetic rats
Table 1

Inhibition by jasplakinolide of mast cell degranulation caused by bradykinin and antigen in vitro

\begin{tabular}{llll}
\hline & \multicolumn{2}{l}{ Histamine release (\%) } \\
\cline { 2 - 4 } & Medium & DNP-BSA & Bradykinin \\
\hline Vehicle & $8.34 \pm 1.31$ & $31.67 \pm 7.71^{+}$ & $45.92 \pm 7.44^{+}$ \\
Jasplakinolide & $7.83 \pm 0.22$ & $17.27 \pm 3.87^{+, *}$ & $26.39 \pm 4.62^{+, *}$ \\
\hline
\end{tabular}

Isolated mast cells were preincubated with $1 \mu \mathrm{M}$ jasplakinolide or vehicle, $1 \mathrm{~h}$ before stimulation. IgE-sensitized mast cells were challenged with antigen (DNP-BSA) $(0.05 \mu \mathrm{g} / \mathrm{ml})$ and normal mast cells with bradykinin $(50 \mu \mathrm{g} / \mathrm{ml})$, for $1 \mathrm{~h}$ at $37{ }^{\circ} \mathrm{C}$. Data are expressed as mean \pm SEM. ${ }^{+} p<0.001$ compared with medium-stimulated cells; $*_{p}<0.01$ compared with the respective positive control cells. Data represent at least three separate experiments.

exhibited a large increase in fluorescence intensity (Fig. 2B), when compared with normal mast cells (Fig. 2A), in parallel with a decrease in cell size (Fig. 2B). Diabetic mast cells exhibited a 2-fold increase in fluorescence intensity (Fig. 2C) and a 2.5-fold decrease in cell diameter as compared to normal mast cells (Fig. 2D).

\section{Effect of jasplakinolide on normal mast cell reactivity in vitro}

In order to examine whether stabilization of filamentous actin might contribute to mast cell refractoriness, cells isolated from naive rats were incubated with jasplakinolide $(1 \mu \mathrm{M})$, an agent known to enhance actin polymerization and alter cellular
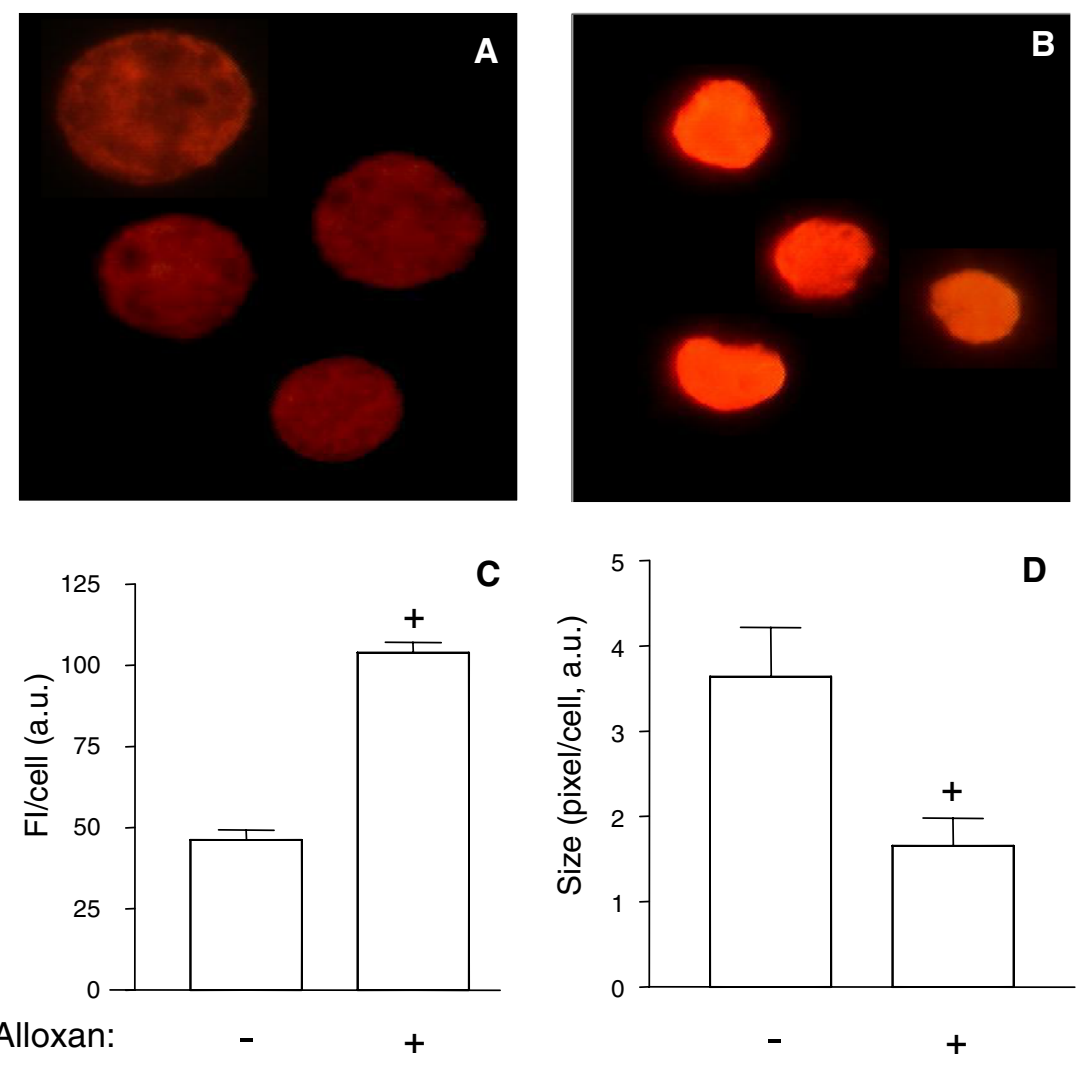

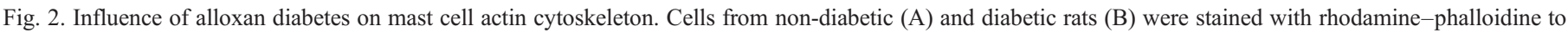

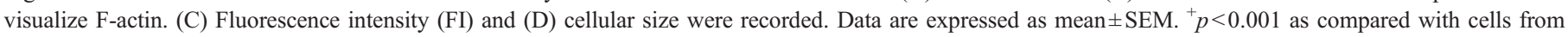
normal animals. Data represent at least three independent experiments. 
actin cytoskeleton (Miyake et al., 2001). Table 1 indicates that IgE-sensitized mast cells when incubated with jasplakinolide exhibited a less intense secretory response following antigen stimulation. Similar refractoriness was noted when bradykinin was used as stimulus (Table 1).

Analysis of apoptotic rate in mast cells isolated from diabetic rats

Aiming to investigate the possibility of apoptosis being involved in the refractoriness of diabetic rat mast cells, we used hypotonic PI method and flow cytometry to evaluate the apoptosis of mast cells obtained from diabetic or normal rats. A summary of the apoptosis data is shown in Fig. 3. We noted that mast cells from diabetic rats exhibited a marked increase in the apoptotic rate as compared with those from
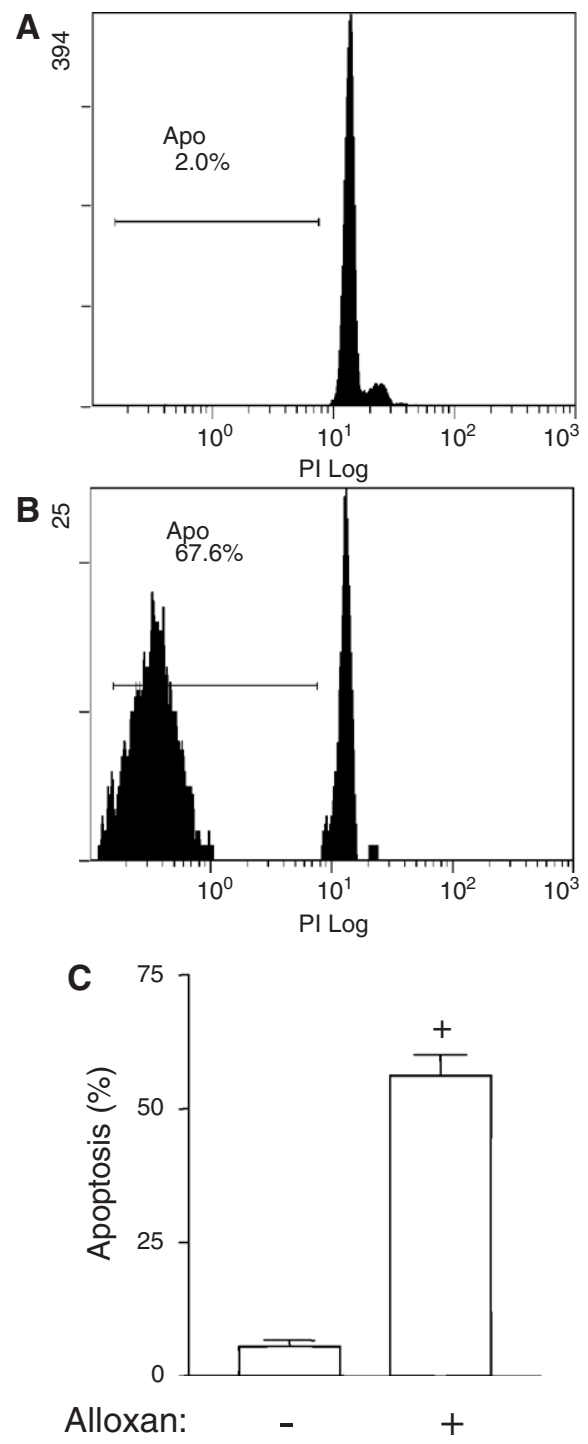

normal rats (Fig. 3B and A, respectively). Quantification analysis showed that diabetic mast cells were about $66 \%$ apoptotic, while normal mast cells about $2 \%$ apoptosis $(p<0.001)$ (Fig. 3C).

Western blot analysis of apoptosis-related molecules in diabetic mast cells

Several apoptosis-related molecules include proteins of the Bcl-2 family, which consists of both pro-apoptotic molecules such as Bax and anti-apoptotic molecules such as Bcl-2 (Adams and Cory, 1998; Korsmeyer, 1999). As illustrated in Fig. 2, Bax protein expression in mast cells from diabetic rats significantly increased compared with cells from control rats (part D), under conditions where Bcl-2 protein expression remained unchanged (part E).
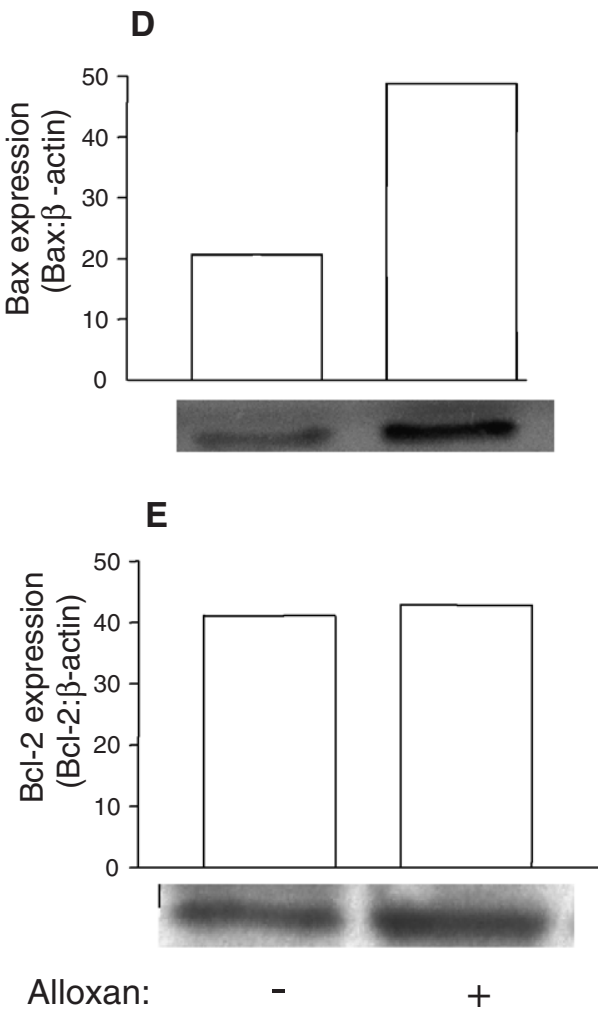

Fig. 3. Influence of alloxan diabetes on mast cell apoptosis. Isolated cells from normal (A) or diabetic (B) rats were labeled with propidium iodide. Apoptotic rate (\% in Apo gate) is indicated in each fluorescence histograms. (C) Data expressing percentage of apoptotic mast cells from four independent experiments are represented. (D) Expression of Bax and (E) Bcl-2 proteins in mast cells from normal and diabetic animals was determined by Western blot. Each blot is representative of five experiments. Data were normalized to $\beta$-actin and represented as the ratio between expression of Bax and Bcl-2: $\beta$-actin. ${ }^{+} p<0.001$ as compared with mast cells from normal rats. 
Table 2

Influence of steroid receptor antagonist RU 486 on the degranulation of mast cells from diabetic rats in vitro

\begin{tabular}{llll}
\hline Condition & \multicolumn{3}{l}{ Histamine release (\%) } \\
\cline { 2 - 4 } & Treatment & Medium & DNP-BSA \\
\hline Control & Vehicle & $2.21 \pm 0.51$ & $20.78 \pm 0.31^{+}$ \\
& RU 486 & $2.50 \pm 0.60$ & $22.41 \pm 0.41^{+}$ \\
Diabetes & Vehicle & $2.63 \pm 0.31$ & $14.18 \pm 0.60^{+}, *$ \\
& RU 486 & $2.54 \pm 0.33$ & $18.72 \pm 1.34^{+, \#}$ \\
\hline
\end{tabular}

Mast cells were recovered from the peritoneal cavity of normal or diabetic rats under condition of pretreatment with RU $486(20 \mathrm{mg} / \mathrm{kg}$, p.o.) or its vehicle. IgE-sensitized mast cells were challenged with antigen (DNP-BSA) $(0.05 \mu \mathrm{g} /$ $\mathrm{ml}$ ), for $1 \mathrm{~h}$ at $37^{\circ} \mathrm{C}$. Data were expressed as mean \pm SEM. ${ }^{+} p<0.001$ compared with medium-stimulated cells; ${ }^{*} p<0.01$ compared with antigen-stimulated cells from control animals; ${ }^{*} p<0.01$ compared with antigen-stimulated cells from diabetic animals. Data represent at least three independent experiments.

Involvement of glucocorticoids in diabetes-induced refractoriness of mast cells

To evaluate whether steroids could be involved in hyporesponsiveness of diabetic mast cells, the effect of glucocorticoid receptor antagonist RU-486 was then investigated. As illustrated in Table 2, chronic administration of RU $486(20 \mathrm{mg} / \mathrm{kg}$, p.o.) into diabetic rats clearly restored mast cell response to antigen in vitro. It is noteworthy that administration of either dexamethasone $(0.1 \mathrm{mg} / \mathrm{kg}$, s.c.) or corticosterone $(0.5 \mathrm{mg} / \mathrm{kg}$, s.c.) into naive rats led to down-regulation of mast cell secretory function noted after antigen stimulation. Values of histamine release dropped from $23.6 \pm 2.6 \%$ (mean $\pm \mathrm{SEM}$ ) in control mast cells to $10.3 \pm 1.4 \%(n=4 ; p<0.001)$ and $15.4 \pm 2.2 \%(n=5$;
Table 3

Changes in the body weight and plasma glucose levels in alloxan diabetic rats

\begin{tabular}{lllc}
\hline Group & Condition & Body weight $(\mathrm{g})$ & Blood glucose $(\mathrm{mM})$ \\
\hline Control & - & $248 \pm 8$ & $7.06 \pm 0.15$ \\
& Adrenalectomy & $272 \pm 4$ & $6.6 \pm 0.11$ \\
Diabetes & - & $127 \pm 5^{+}$ & $17.23 \pm 1.2^{+}$ \\
& Adrenalectomy & $152 \pm 12$ & $11.13 \pm 0.93^{*}$ \\
Control & - & $240 \pm 10$ & $7.06 \pm 0,15$ \\
& RU 486 & $255 \pm 7$ & $6.87 \pm 0.08$ \\
Diabetes & - & $140 \pm 15^{+}$ & $22.78 \pm 1.59^{+}$ \\
& RU 486 & $161 \pm 11$ & $22.35 \pm 1.33$ \\
\hline
\end{tabular}

Data were expressed as mean $\pm \mathrm{SEM}$ from at least 10 animals. ${ }^{+} p<0.001$ compared with control rats; ${ }^{*} p<0.05$ compared with diabetic rats.

$p<0.001)$ in mast cells from dexamethasone- and corticosterone-treated animals, respectively. Basal histamine release was not modified after steroid treatment (data not shown). Mast cells recovered from dexamethasone-treated rats exhibited an increase in fluorescence intensity (Fig. 4A) and a decrease in cellular size (Fig. 4B), when compared with cells from vehicletreated rats. Higher levels of apoptotic rate (Fig. 4C) and over expression of the pro-apoptotic protein Bax (Fig. 4D) were detected in mast cells from rats treated with dexamethasone, under conditions where no alteration of the anti-apoptotic protein Bcl-2 was noted (Fig. 4E).

Changes in the body weight and plasma glucose levels in alloxan diabetic rats

Estimate made 21 days after alloxan $(40 \mathrm{mg} / \mathrm{kg}$, i.v.) administration into Wistar rats showed that a significant
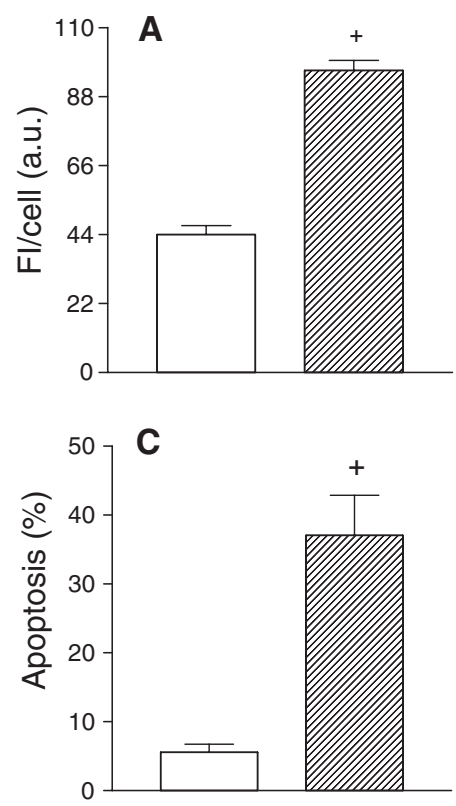
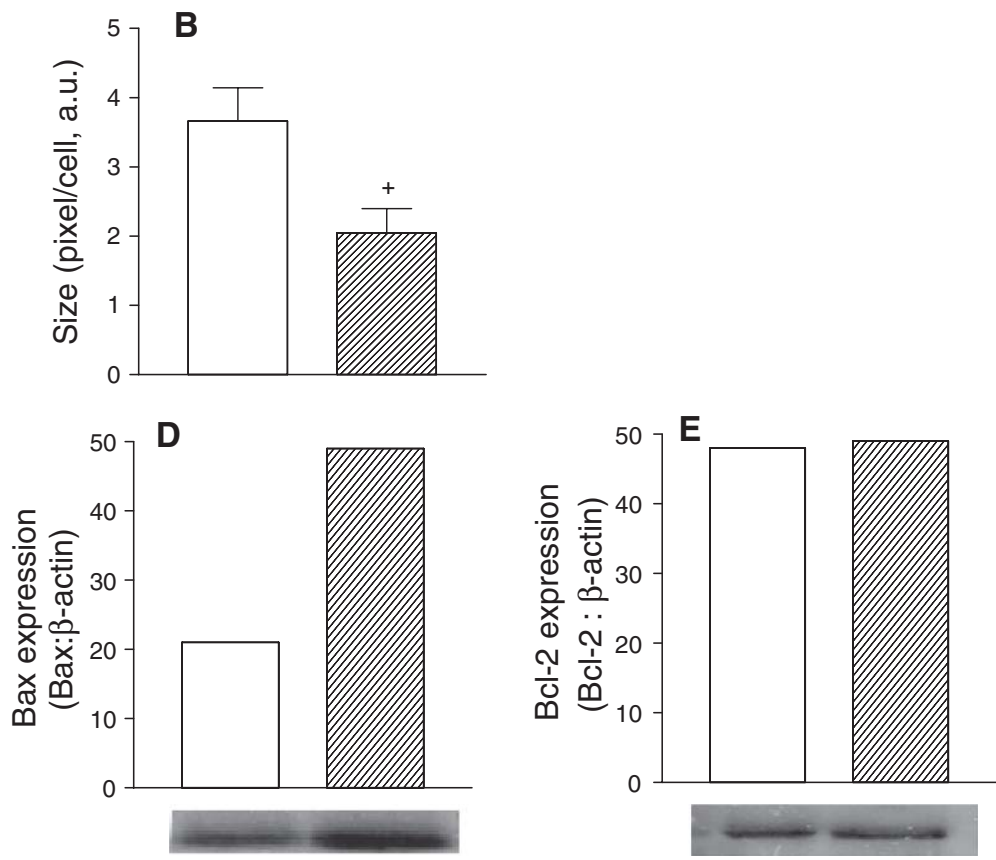

Fig. 4. Effect of dexamethasone treatment $(0.1 \mathrm{mg} / \mathrm{kg}$, s.c.) on mast cells from normal rats. Cells from vehicle- (open columns) and dexamethasone-treated rats (hatched columns) were stained with rhodamine-phalloidine to visualize F-actin. (A) Fluorescence intensity (FI) and (B) cellular size were recorded. (C) Data expressing percentage of apoptotic mast cells (PI staining) from four independent experiments are represented. (D) Expression of Bax and (E) Bcl-2 proteins in mast cells from vehicle- and dexamethasone-treated rats was determined by Western blot. Each blot is representative of three separate experiments. Data were normalized to $\beta$-actin and represented as the ratio between expression of Bax and Bcl-2: $\beta$-actin. ${ }^{+} p<0.001$ as compared with mast cells from normal rats. 
reduction in the body weight and a marked increase in the blood glucose concentrations (Table 3). We also noted that adrenalectomized diabetic rats presented a significant reduction of blood hyperglycemia and no alteration of body weight loss as compared to control animals (Table 3 ), under conditions where RU 486 treatment did not interfere with both parameters analyzed. In another set of experiments we noted that administration of dexamethasone $(0.1 \mathrm{mg} / \mathrm{kg}$, i.p. $)$ into naive rats, during five consecutive days, did not modify blood glucose levels and body weight. Values of blood glucose and body weight were $7.06 \pm 0.15 \mathrm{mM}$ and $241 \pm 10 \mathrm{~g}$ in untreated and $7.4 \pm 0.1 \mathrm{mM}$ and $248 \pm 8 \mathrm{~g}$ (mean $\pm \mathrm{SEM}, n=10)$ in dexamethasone-treated rats, respectively.

\section{Discussion}

We have previously demonstrated that mast cells are downregulated under alloxan diabetes in rats, by a mechanism dependent on increased levels of serum glucocorticoids (Diaz et al., 1996, 1997). Here we report that mast cells from diabetic animals exhibit a large increase in the filamentous actin, as compared with normal mast cells, as well as an increase in the percentage of apoptosis. Diabetic mast cells are also shown to be less responsive to antigen and bradykinin in vitro, phenomenon clearly reversed after treatment of alloxinated rats with steroid receptor antagonist RU 486. Taken together, our findings indicate that there is a causative relationship between increased levels of apoptosis and suppression of mast cell responsiveness associated with diabetic state, in clear dependence on the upregulation of endogenous glucocorticoids.

Mast cells are generally found around blood vessels, predominantly in tissues forming an interface between host and external environment. Their number is mainly dependent on the survival of mature mast cells within the tissue (Metcalfe et al., 1997). Microenvironmental factors such as stem cell factor (SCF) and adhesion molecules play an important role in regulating mast cell numbers and reactivity in the periphery (Puxeddu et al., 2003). In response to antigen, mast cells can release a wide range of preformed and neo-generated mediators by a mechanism associated with a dynamic and complicated filamentous network (Frigeri and Apgar, 1999). There is evidence that actin filaments are structures whose overall abundance is related to the balance of polymerization and depolymerization at the filament ends as well as to the number of ends available for such exchange (Castellino et al., 1995).

Herein we demonstrate that staining of actin filaments with rhodamine-phalloidine reveals obvious differences in actin organization between control and mast cells from diabetic rats. Control cells stained slightly, whereas diabetic mast cells presented a marked increase in the fluorescence intensity and reduction in cell diameter. In parallel we noted that purified mast cells from diabetic rats were hyporesponsive to antigen and bradykinin stimulation in vitro as attested by histamine release. Since stored histamine in diabetic mast cell granules was shown to be the same as that found in normal cells (Diaz et al., 1996; de Oliveira Barreto et al., 2003), we could infer that alloxan-induced diabetes did promote a decrease in the reactivity of mast cells rather than their degranulation. Reinforcing the above observation, we showed that incubation of mast cells with alloxan in vitro did not modify their response to antigen. As observed for histamine, diabetic mast cells released lower levels of $\mathrm{PGD}_{2}$ under conditions of antigen stimulation as compared to mast cells from non-diabetic rats. Taking together, these findings indicate that hyporeactivity associated with diabetes is not a phenomenon restricted to immunological stimulation, also affecting preformed and neogenerated mediator release from mast cells.

In another series of experiments we demonstrated that treatment of naive mast cells with jasplakinolide, a compound with the ability to stabilize actin microfilaments and to promote actin polymerization, clearly inhibited mast cell degranulation, supporting the interpretation that stabilization of filamentous actin may indeed lead to down-regulation of mast cell secretion. Of note, stabilization and polymerization of actin microfilaments are pivotal features in the process of apoptosis (Posey and Bierer, 1999). In fact, our findings revealed that mast cells from alloxan diabetic rats presented a drastic increase in the number of apoptotic cells as attested by flow cytometry. It is interesting to emphasize that upregulation of $\mathrm{Bcl}-2$ and $\mathrm{BclX}_{\mathrm{L}}$ by stem cell factor is a crucial mechanism associated with mast cell survival (Iemura et al., 1994; Maurer et al., 2000). In our conditions, the expression of the anti-apoptotic protein recovered from diabetic rats remained unchanged. Nevertheless, these cells were shown to over express the pro-apoptotic protein Bax, suggesting that this protein may play a role in processing apoptotic signalling in mast cells under diabetic conditions.

Early studies demonstrated that glucocorticoids induce down-regulation of mast cell recruitment, development, survival and activation at different body sites, by inhibiting the local production of factors such as stem cell factor, IL-3 and IL-4 (Metcalfe et al., 1997). We and others described a rise in the serum corticosterone levels in parallel with an increase in adrenal gland/body weight rate following diabetes caused by alloxan treatment in rats (Diaz et al., 1997; Welxer and McMurtry, 1983). In this study we verified that treatment of diabetic rats with steroid receptor antagonist RU 486 impaired the reduction of histamine secreted from mast cells, indicating that increased levels of corticosterone might be involved in down-regulation of mast cells under diabetic conditions. It has been previously shown that RU 486 is also an antagonist of progesterone receptor (Cadepond et al., 1997). However, it should be considered that the animals used were males, the affinity of RU 486 for progesterone is lower than that for the glucocorticoid receptors and that mast cells have more receptors to glucocorticoids than for progesterone. In addition, progesterone levels were reported to be reduced in alloxinated rats (Piyachaturawat et al., 1984). Thus, we could suggest that progesterone might not play a relevant role in the mast cell refractoriness under diabetic condition.

In fact, we noted that treatment with either dexamethasone or corticosterone clearly affected mast cell responsiveness as attested by reduced histamine secretion following antigen 
challenge. Since steroids did not prevent binding of $\operatorname{IgE}$ molecules to mast cell receptors (Metcalfe et al., 1997), inhibition of biochemical processes of mediator release, subsequent to antigen-antibody reaction on the cell surface, should be considered. Increased levels of filamentous actin and apoptosis were detected in mast cells after treatment of normal rats with dexamethasone. One possible mechanism underlying the former could be related to actin filament stabilization (Castellino et al., 1995) or increase in proteins which regulate interaction among cytoskeleton proteins such as caldesmon (Velaz et al., 1989). We also noted that though effective to inhibit mast cell refractoriness in diabetic rats, bilateral adrenalectomy but not treatment with RU 486 effectively reduced the increase in blood glucose levels. One potential explanation for this discrepancy is that extraction of the whole gland could be a more effective process to block the activity of endogenous hyperglycemic substances such as steroid hormones and also catecholamines. Treatment with insulin also restored mast cell number (Diaz et al., 1996) and reactivity (data not shown) without interfering with hyperglycemia in diabetic rats, reinforcing the idea that mast cell hyporesponsiveness is a phenomenon probably associated with a severe reduction in insulin secretion rather than an increase in blood glucose levels.

In conclusion, our findings led us to propose that the refractoriness of mast cells under diabetic condition is accounted for by increased levels of apoptosis, resulting from an upregulation of endogenous glucocorticoid hormones.

\section{Acknowledgements}

We thank Dr. Wilson Savino for his helpful reading and suggestions. This study was supported by grants from Conselho Nacional de Desenvolvimento Científico e Tecnológico (CNPq), Fundação de Amparo à Pesquisa do Estado do Rio de Janeiro (FAPERJ) and Programa de Auxílio à Pesquisa (PAPES 3/ FIOCRUZ), Brazil.

\section{References}

Adams, J.M., Cory, S., 1998. The Bcl-2 protein family: arbiters of cell survival. Science 281 (5381), 1322-1326.

Afanasyev, V.N., Korol, B.A., Matylevich, N.P., Pechatnikov, V.A., Umansky, S.R., 1993. The use of flow cytometry for the investigation of cell death. Cytometry 14 (6), 603-609.

Barnes, P.J., 1997. Nuclear factor-kappa B. International Journal of Biochemistry and Cell Biology 29 (6), 867-870.

Bottini, N., Fontana, L., 1999. Asthma and diabetes. Lancet 354 (9177), $515-516$.

Burgess, T.L., Kelly, R.B., 1987. Constitutive and regulated secretion of proteins. Annual Review of Cell Biology 3, 243-293.

Cadepond, F., Ulmann, A., Baulieu, E.-E., 1997. RU486 (MIFEPRISTONE): mechanisms of action and clinical uses. Annual Review of Medicine 48, $129-156$.

Cameron, O.G., Kronfol, Z., Greden, J.F., Carroll, B.J., 1984. Hypothalamicpituitary-adrenocortical activity in patients with diabetes mellitus. Archives of General Psychiatry 41 (11), 1090-1095.

Cardwell, C.R., Shields, M.D., Carson, D.J., Patterson, C.C., 2003. A metaanalysis of the association between childhood type 1 diabetes and atopic disease. Diabetes Care 26 (9), 2568-2574.
Castellino, F., Heuser, J., Marchetti, S., Bruno, B., Luini, A., 1992. Glucocorticoid stabilization of actin filaments: a possible mechanism for inhibition of corticotropin release. Proceedings of the National Academy of Sciences of the United States of America 89 (9), 3775-3779.

Castellino, F., Ono, S., Matsumura, F., Luini, A., 1995. Essential role of caldesmon in the actin filament reorganization induced by glucocorticoids. Journal of Cell Biology 131 (5), 1223-1230.

Cohen-Saidon, C., Nechushtan, H., Kahlon, S., Livni, N., Nissim, A., Razin, E., 2003. A novel strategy using single-chain antibody to show the importance of Bcl-2 in mast cell survival. Blood 102 (7), 2506-2512.

de Oliveira Barreto, E., de Frias Carvalho, V., Diaz, B.L., Balduino, A., Cordeiro, R.S., Martins, M.A., Rodrigues e Silva, P.M., 2003. Adoptive transfer of mast cells abolishes the inflammatory refractoriness to allergen in diabetic rats. International Archives of Allergy and Immunology 131 (3), 212-220.

Diaz, B.L., Serra, M.F., Alves, A.C., Pires, A.L., Correa, F.M., Cordeiro, R.S., Martins, M.A., Silva, P.M., 1996. Alloxan diabetes reduces pleural mast cell numbers and the subsequent eosinophil influx induced by allergen in sensitized rats. International Archives of Allergy and Immunology 111 (1), $36-43$.

Diaz, B.L., Barreto, E.O., Cordeiro, R.S.B., Martins, M.A., Silva, P.M.R., 1997. Antigen-induces pleural eosinophilia is suppressed in diabetic rats: role of glucocorticoid hormones. Memórias do Instituto Oswaldo Cruz 92 (Supp1 II), 219-222.

Diaz, B., Barreto, E., Cordeiro, R., Perretti, M., Martins, M., Silva, P., 2001. Enhanced serum glucocorticoid levels mediate the reduction of serosal mast cell numbers in diabetic rats. Life Sciences 68 (26), 2925-2932.

Frigeri, L., Apgar, J.R., 1999. The role of actin microfilaments in the downregulation of the degranulation response in RBL-2H3 mast cells. Journal of Immunology 162 (4), 2243-2250.

Iemura, A., Tsai, M., Ando, A., Wershil, B.K., Galli, S.J., 1994. The c-kit ligand, stem cell factor, promotes mast cell survival by suppressing apoptosis. American Journal of Pathology 144 (2), 321-328.

Klip, A., Marette, A., Dimitrakoudis, D., Ramlal, T., Giacca, A., Shi, Z.Q., Vranic, M., 1992. Effect of diabetes on glucoregulation. From glucose transporters to glucose metabolism in vivo. Diabetes Care 15 (11), $1747-1766$

Korsmeyer, S.J., 1999. BCL-2 gene family and the regulation of programmed cell death. Cancer Research 59 (Suppl 7), 1693s-1700s.

Maurer, M., Tsai, M., Metz, M., Fish, S., Korsmeyer, S.J., Galli, S.J., 2000. A role for Bax in the regulation of apoptosis in mouse mast cells. Journal of Investigative Dermatology 114 (6), 1205-1206.

Metcalfe, D.D., Baram, D., Mekori, Y.A., 1997. Mast cell. Physiological Reviews 77 (4), 1033-1079.

Miyake, K., McNeil, P., Suzuki, K., Tsunoda, R., Sugai, N., 2001. An actin barrier to resealing. Journal of Cell Science 114 (19), 3487-3494.

Nicoletti, I., Migliorati, G., Pagliacci, M.C., Grignani, F., Riccardi, C., 1991. A rapid and simple method for measuring thymocyte apoptosis by propidium iodide staining and flow cytometry. Journal of Immunological Methods 139 (2), 271-279.

Olesen, A.B., Juul, S., Birkebaek, N., Thestrup-Pedersen, K., 2001. Association between atopic dermatitis and insulin-dependent diabetes mellitus: a casecontrol study. Lancet 357 (9270), 1749-1752.

Pendleton, A., Pope, B., Weeds, A., Koffer, A., 2003. Latrunculin B or ATP depletion induces cofilin-dependent translocation of actin into nuclei of mast cells. Journal of Biological Chemistry 278 (16), 14394-14400.

Piyachaturawat, P., Peungvicha, P., Limlomwongse, L., Krishnamra, N., 1984. Depression of estrogen-induced uterine peroxidase in alloxan-diabetic rats. Journal of Steroid Biochemistry 21 (6), 685-690.

Posey, S.C., Bierer, B.E., 1999. Actin stabilization by jasplakinolide enhanced apoptosis induced by cytokine deprivation. Journal of Biological Chemistry 274 (7), 4259-4265.

Puxeddu, I., Piliponsky, A.M., Bachelet, I., Levi-Schaffer, F., 2003. Mast cells in allergy and beyond. International Journal of Biochemistry and Cell Biology 35 (12), 1601-1607.

Roy, M., Collier, B., Roy, A., 1990. Hypothalamic-pituitary-adrenal axis dysregulation among diabetic outpatients. Psychiatry Research 31 (1), $31-37$. 
Roy, M.S., Roy, A., Brown, S., 1998. Increased urinary-free cortisol outputs in diabetic patients. Journal of Diabetic Complications 12 (1), 24-27.

Schoneveld, O.J., Gaemers, I.C., Lamers, W.H., 2004. Mechanisms of glucocorticoid signaling. Biochimica and Biophysica Acta. Molecular and Cell Biology of Lipids 1680 (2), 114-128.

Shore, P.A., Burkhalter, A., Cohn, V.H., 1959. A method for the fluorimetric assay of histamine in tissue. Journal of Pharmacology and Experimental Therapeutics 127, 182-186.

Taskinen, M.R., Lahdenpera, S., Syvanne, M., 1996. New insights into lipid metabolism in non-insulin-dependent diabetes mellitus. Annals of Medicine 28 (4), 335-340.

Tinkelman, D., King, S., 1979. Severe asthma and volatile diabetes mellitus in the same patient: a treatment dilemma. Journal of Allergy and Clinical Immunology 64 (3), 223-226.
Velaz, L., Hemric, M.E., Benson, C.E., Chalovich, J.M., 1989. The binding of caldesmon to actin and its effect on the ATPase activity of soluble myosin subfragments in the presence and absence of tropomyosin. Journal of Biological Chemistry 264 (16), 9602-9610.

Welxer, B.C., McMurtry, J.P., 1983. Resistance of obese and non-obese, spontaneously hypertensive rats to alloxan-induced diabetes. Life Sciences 33 (11), 1097-1103.

White, S.R., Williams, P., Wojcik, R.K., Sun, S., Hietmstra, P.S., Rabe, K.F., Dorscheid, D.R., 2001. Initiation of apoptosis by actin cytoskeleton derangement in human. American Journal of Respiratory Cell and Molecular Biology 24 (5), 282-294. 